\title{
Policy Implementation Permenkes No.2562/Menkes/XII/2011 about Delivery Guarantee in North Konawe, Province of Southeast Sulawesi
}

\author{
Sri Suwitri ${ }^{1} \&$ Martaya $^{1}$ \\ ${ }^{1}$ Doctoral Program of Public Administration, Faculty of Social and Political Sciences, Diponegoro University, \\ Semarang, Indonesia \\ Correspondence: Sri Suwitri, Doctoral Program of Public Administration, Faculty of Social and Political \\ Sciences, Diponegoro University, Building of Postgraduate Diponegoro University; 5th Floor, Imam Bardjo, SH \\ Street No. 3-5 Semarang, Indonesia. Tel: 62-857-2697-2565 or 62-856-4113-0512. E-mail: \\ programdap@yahoo.com
}

Received: June 10, 2014

Accepted: July 21, 2014 Online Published: August 29, 2014

doi:10.5539/jms.v4n3p192

URL: http://dx.doi.org/10.5539/jms.v4n3p192

\begin{abstract}
The implementation of Jampersal policy in North Konawe has been running good. The target programs in North Konawe District also have appropriate regulations. The Service procedures have been implemented as expected. Likewise, the types of services provided. The procedure has the appropriate funding procedures. The Society of North Konawe greatly benefit for antenatal care, childbirth and postpartum. However, there are still some obstacles in the implementation.
\end{abstract}

Keywords: the public policy of delivery guarantee, policy implementation, obstacle factors

\section{Introduction}

Infant Mortality Rate (IMR) and Maternal Mortality Rate (MMR) in Indonesia are still quite high compared to other ASEAN countries. According to data from the Indonesian Demographic Health Survey (IDHS) 2007, MMR 228 per 100,000 live births, IMR 34 per 1,000 live births, the infant mortality rate of Newborn (NB) 19 per 1,000 live births. Under the global agreement (Millennium Development Goals/MDG's 2000) in 2015, maternal mortality is expected to decline, from 228 to 102 in 2007, and infant mortality decreased from 34 to 23 in 2007. MMR reduction efforts should be focused on the direct cause of maternal death, which occurred $90 \%$ during labor and immediately after baseline is bleeding (28\%), eclampsia (24\%), infection (11\%), complications pueperium $8 \%, 5 \%$ obstructed, abortion $5 \%, 5 \%$ obstetric trauma, embolism $3 \%$, and others $11 \%$ (SKRT 2001). Maternal mortality is also causing some delay risk factors (Three Delays), of which the late prenatal care (delayed making a decision), late in the delivery of services as health workers, and late to the health facility at the time in a state of emergency.

One of prevention efforts is to conduct births attended by health personnel in health facilities in accordance with the Service Standard of Maternal and Child Health Programs (KIA). According to the results Riskesdas 2010, delivered by health workers in poor target group (quintile 1) had reached about $69.3 \%$. While deliveries conducted by health workers at health facilities reached $55.4 \%$. Because of these things the Indonesian government issued Minister Regulation.2562/Menkes/XII/2011 on Delivery Guarantee. Delivery Guarantee is intended to eliminate financial barriers for pregnant women to get labor warranty, which includes prenatal care, postpartum care, including family planning postpartum, and newborn care. Delivery Guarantee is expected to reduce the occurrence of the Three Delays so as to accelerate the achievement of the MDG goals 4 and 5.

The number of infant deaths in North Konawe Southeast Sulawesi on 2006-2010 fluctuated, however, based on exponential trendline shows the trend of increasing number of deaths. Tendency of increase in IMR in North Konawe Southeast Sulawesi is very likely to exceed the figures above, it could be because the number of infant deaths was reported only from a health care facility or that can be monitored by health workers. In addition, the number of reported deaths is strongly influenced by the completeness of reporting and recording of deaths in the Health Department.

Maternal Mortality Rate (MMR) is useful to describe the level of awareness of healthy behavior, nutritional status and maternal health, environmental health conditions, the level of health care, especially for pregnant 
women, health care during childbirth and the puerperium. Those things are pushed to do research, policy implementation Permenkes No.2562/Menkes/XII/2011 about Delivery Guarantee in North Konawe Province of Southeast Sulawesi.

\section{Method}

The experiment was conducted using a qualitative approach and data collection techniques such as observation, interviews, and focus group discussion. The data source of this study consisted of primary data and secondary data. The main instrument in this study is the researchers themselves. This study will also use other supporting instruments such as observation, interview guidelines and guidance documentation. Analyzing qualitative data in this study will be carried out by the steps: data reduction, data display, conclusion, and verification. This study uses the technique of data through kredilitas validity, transferability, dependability and confirmability. Limitations of this study because it is done only in North Konawe, while Jampersal policy applies throughout Indonesia, so we need more research in several provinces in Indonesia, which represents Jampersal conditions in urban, developed areas, and border areas.

\section{Results}

Implementation of policies according to Jones (1994:166) is a set of activities directed toward putting a program into effect. Implementation is an activity that is intended to operate a program, in this program operate further noted the presence of three (3) activities that need to be done, namely: "organization, interpretation, application".

In the process of policy implementation, there are also: (1) the policy/program to be implemented, (2) the target group, (3) implementing elements (implementor).

One by one the theoretical analysis on the policy guarantees delivery in North Konawe are as follows:

(1) The existence of policies/programs that will be implemented

Policies or programs that will be implemented is the Minister Regulation No.2562/Menkes/XII/2011 on Technical Guidelines of Jampersal-regulations for Delivery Guarantee Program. This policy is structured to provide a reference for the Government, Provincial Government, District Government/City and related parties who hold Delivery Guarantee in order to:

a. Increased coverage of prenatal care, delivery assistance, and post-partum maternal care by qualified health personnel;

b. Increased coverage of newborn care, family planning, and treatment of postpartum maternal complications, childbirth, postpartum, and newborn, postpartum family planning by a qualified healthcare professional, and;

c. Implementation of financial management that is efficient, effective, transparent, and accountable.

This minister regulation since 2014 has been merged in the policy of the Social Security Agency of Health (Badan Penyelenggara Jaminan Sosial/BPJS), but the implementation of delivery guarantee policies is still face the same barrier and booster aspects. The purpose of this policy is achieved in North Konawe.

\section{(2) The Target Group}

The target group of this policy is entitled to receive services that are directly related to pregnancy and childbirth even normal or at high risk for complications or prevent maternal and neonatal of delivery process. The limit service time up to 28 days in infants and up to 42 days in postpartum mothers. It is a time limit for service of PNC but not as a service delivery deadline which is not directly related to labor and or prevention of maternal and neonatal deaths due to a birth process. In North Konawe, this policy has been right on target, which includes:

1) Expectant Mother,

2) Maternal,

3) Postpartum women (up to 42 days postpartum),

4) Newborns (up to age: 28 days).

(3) Implementing Elements (Implementor)

Implementing elements of the policy is dependent on the type of service provided, namely:

1) postpartum care is guaranteed by 4 times by midwives unless postpartum care with complications will be referred to the hospital.

2) family planning services (Keluarga Berencana/KB) conducted by midwives, health center and District Health Office of North Konawe, with the following procedures: 
a. The village midwife and health center clinic are making a plans of contraceptive devices and drugs requirements are needed for family planning services at health center clinic and midwives who serve Delivery Guarantee program. Furthermore, the list of requirement is sent to District Health Office of North Konawe as managers of family planning programs in North Konawe.

b. The village midwife as implementor of Delivery Guarantee program is making a plan of free contraceptives requirements for family planning services and then forwards the request to the nearest health center in the village midwife's area of residence.

c. Local government clinic after getting free contracepves from the Department of Health of North Konawe for further distribute the free contracepves to the village midwives with the appropriate amount proposed.

d. Family planning services at health facilities continued:

1) Equipment and contraceptive drugs (contracepves free) provided by BKKBN.

2) The village midwives who serving Jampersal make plans contraceptive devices and medicines requirements needed for services in family planning (keluarga Berencana/KB) in the hospital and then sent the list of those needs to SKPD who managing family planning programs in the District/Municipality.

3) Service of family planning in health care continued service to be part of the acceptance according to rate of INA CBG's planning services/KB with Jampersal/Delivery Guarantee has been running good. Coordination between field workers of KB (field officers), midwife, health facilities (local government clinic/hospital), Department of Health as Management Team also the BKKBN of North Konawe and Southeast Sulawesi BKKBN too.

\section{e. Postpartum Care Service}

The village midwives is Delivery Guarantee service providers that perform family planning service/KB after delivery process in North Konawe have also made the recording and reporting of contraceptive devices and drugs are accepted and used in accordance to recording and reporting formats and sent to the Department of Health in North Konawe.

Although Konawe has undertaken Permenkes on Delivery Guarantee No.2562/Menkes/XII/2011 well, but still faces some obstacles, namely:

\subsection{The Obstacle Factors}

\subsubsection{The Obstacles in Implementation of Policy}

\section{a. Transportation between villages}

A far distance and lack of transport is still to be an obstacle. Many areas are still minimal lighting, whereas in some cases, the village midwife was forced to go to the patient. This can endanger the village midwife who is a young woman's average age was 20 years old and unmarried. As an example of a dangerous risk is the occurrence of rape against a village midwife.

\section{b. Communication tools}

Communication tools are also a barrier. Although the mobile phone (HP) has a lot in North Konawe, but HP signal is lacking, some areas not covered by the communication signal, i.e. Tetewatu village, Landikima village, Hialu village, Landawe village, and the Asera Village.

c. The absence of ambulance

North Konawe has no ambulances for the purposes of implementation of Minister Regulation No.2562/Menkes/XII/2011 on Delivery Guarantee. If you need an ambulance because the patient's condition should be referred to hospital in North Konawe or even to Kendari only use the resident's car. The loaning of resident's car as ambulances carried out by way of budgetary funds through the village or Allocation Village Fund (ADD ) to rent a resident's car.

d. Some villages are still not available for electricity from the State Electricity Company (PLN).

This is a barrier to implementation Permenkes No.2562/Menkes/XII/2011 about the delivery guarantee program. Besides that will be hard for the village midwives to come to the home of the patient, or otherwise, it was to be hard for brought patients to the village midwife's home, also prone to the safety of the village midwife. Vulnerable to rape and vehicle accidents, given the road conditions are not good enough for traveling with a two-wheeled vehicle at night, while the ambulance car also is not yet available. To resolve this condition, the village midwife who knows the circumstances of pregnant women who almost gave birth, are advised to stay at 
Rumah Tunggu at the village midwife's home. Dark conditions for ambulance car coped with lights sign car with the intention of asking for attention.

e. Residence in the village are not available

Obstacles experienced by the village midwife on duty outside the village residence is often not available. The absence of living quarters for the village midwife makes the village midwives have no Rumah Tunggu for the patient. These barriers can be overcome with some community leaders or village chief in the village provides housing for village midwives and Rumah Tunggu.

\section{f. Claims Jampersal not disbursed}

Jampersal/Delivery Guarantee still occur where claims cannot be cashed. In accordance Minister Regulation No.2562/Menkes/XII/2011 on Delivery Guarantee, after the service is completed, the funds can be claimed as Jampersal's salary of the village midwife, but sometimes there are some that hampered redemption.

g. Tools and health facilities are lacking

The lack of health facilities and the tools perceived by the midwife as an obstacle. Due to economic constraints, not all village midwives have health equipment. Some midwives who come from families with sufficient economic capacity, can buy some medical equipment such as stethoscopes, thermometers, and pregnancy check tool. But not all midwife can afford to buy their own. To overcome this, the midwife placed in villages adjacent to each other to lend medical equipment until get equipment assistance from the Department of Health .

h. Delivery guarantee (Jaminan Persalinan/Jampersal)'s rooms not have a clean water source (PAM/boreholes)

Jampersal's room provided in health centers, sub health centers, and Rumah Tunggu at midwife's house. These rooms in addition to a shortage of medical equipment, facilities and infrastructure, the Jampersal's room also often lack clean water either from the Regional Water Company and artificial wells population such as boreholes.

i. Facilities and infrastructure at the health center clinic is still lacking.

Infrastructure constraints are also felt in the health center clinic. If forced to patients must be referred by midwives to the health center, the health center was often a shortage of facilities and infrastructure. To overcome this problem forced the patient was referred to the Hospital of North Konawe.

\subsubsection{The Obstacles in the Target Group}

Public participation is still lacking in achieved the success of the Jampersal/Delivery Guarantee program. Not all pregnant and gave birth woman wants to get service from a village midwife with facility of Permenkes No.2562/Menkes/XII/2011 about Delivery Guarantee. Although free, often, there are patients who prefer rescued by Shaman than midwives, although health workers already do the best service. The reason they have a subscription with shaman's baby and feels have a more steady conviction with the help of the shaman's baby. To address this, the Department of Health together with the village midwives performing socialization to society to use the services of village midwives with program Permenkes No. 2562/Menkes/XII/2011 about the delivery guarantee. The other way is the health service training village midwives perform together against shamans of the baby, so shaman's baby in North Konawe become skilled and professional.

\subsection{The Booster Factors}

There are booster factors in implementing elements, namely:

a. Serial communication between residents and village midwives faster for the purposes of:

- determine the condition of the mother during pregnancy, birth and postpartum (puerperal)

- $\quad$ when the midwife went for just one day or even long enough for an errand or leave. Midwives usually have pockets of labor (note of portograf) about the condition of the patient. When the note of portograf was written time patients give birth, the midwife generally do not dare to go outside the village, if forced to leave the village, the village midwife will leave messages immediately to word of mouth, and the midwife will refer to the midwife other villages closest to submit portograf remarks about the patient's condition.

b. Installation stickers P4 (Program of Delivery Planning and Complications Prevention/Program Perencanaan Persalinan dan Pencegahan Komplikasi) installed in houses of pregnant women, and facilitate community midwife supervise and control the condition of pregnant women. Stickers are printed by the 
Department of Health, then submitted to the village midwives throughout North Konawe to be installed in houses where there is a pregnant woman.

c. Childbirth and the puerperium financed Jampersal has made people feel lighter in terms of labor costs and midwife services.

d. Costs or fees midwives who use the bank transfer is making midwife has saved eased and it is making midwife's motivation was booster. Procedure for transfer fees are usually from the Department of Health to the Health Center Clinic and then transferred from the clinic to the village midwife immediately.

e. The cards were made by the health center clinic and the fund cash per quarter. This relieves the village midwife either in the provision of portograf's record and distribution of midwife's salary.

f. Provided operational vehicle for the midwife, they are motorcycle from Local Government of North Konawe as well as incentives for village midwives are sufficient.

g. Village midwives in North Konawe especially those from outside the area of North Konawe feel happy serving in North Konawe. They feel they can interact with a new environment and new people in the task, as well as getting a lot of work experience that has never been obtained while in town.

\section{Discussions}

There are three (3) things that can determine the success of policy implementation, namely (1) the existence of policies/programs that will be implemented; (2) the target group; (3) implementing elements (implementor). However, the implementation of Delivery Policy in North Konawe, only the executive element (implementor) which causes the program implemented on target and achieved policy objectives. Implementation of this policy in North Konawe has been going well although not optimal support on policy support and the target group support, namely:
a. Expectant Mother,
b. Maternal,
c. Postpartum women (up to 42 days postpartum),
d. Newborns (up to age: 28 days).

Implementing elements becomes the most important aspect in optimizing implementation of delivery guarantee policy in North Konawe, such as:

\section{Service procedures}

Implemented in midwife's residence for examination or birth or otherwise, the midwife may visit patients if needed.

a. Initial procedure is noted the patient on the portograf record, next the midwife fill in some cards, namely;

1) ANC Card,

2) Mother Card from midwives,

3) The new birth certificate signed by midwives and village heads,

4) Pertograf, that is patients are attended by midwives of Delivery Guarantee Program/Jampersal or usually called record of deliver.

b. The next procedure midwife put a sticker on houses where pregnant women reside.

c. If the patient needs a referral, the midwife can refer to a health center clinic or hospital.

2. The type of services provided are

a. The first level of service delivery;

b. Advanced Level of Service Delivery;

c. Preparation Referral Services;

d. Service postpartum (Post Natal Care)

3. The procedure for funding

Once the service has been completed, namely the mothers since pregnancy until delivery, postpartum and infants aged 28 days, then the midwife can claim expenses of Delivery Guarantee/Jampersal by:

1) village midwife should submit as folows: 
a. ANC card

b. Mother card from midwives

c. The new birth certificate signed by midwives and village heads

d. Pertograf, history records of delivery service by midwife to Head of Health Central Clinic.

2) Head of health center clinic claims to the Department of Health, Delivery Guarantee/Jampersal's treasurer.

3) Reduced verification team to verify the truth of the claim

4) Since verification, \pm 1 weeks later the money down/cash.

Society of North Konawe greatly benefit in antenatal care, childbirth, and postpartum because of familial and professional services by implementing elements, despite the obstacles in implementing element are still quite a lot but the implementor work professionally to cover the shortfall in the other elements, they are: (1) policies/programs that will be implemented and (2) the target group.

The obstacles in implementing elements, namely:

a. Communication between midwife with government officials and the public.

b. Transportation for the village midwife to reach resident or otherwise due to remote locations and means of running is not good enough and some areas not yet reached by PLN.

c. Healthcare tools

d. Procurement ambulance

e. Residence for midwife

f. Availability of water in the room of delivery guarantee/Jampersal service

g. Disbursement of delivery guarantee/Jampersal's funds sometimes too late.

Central Government, Provincial Governments and Local Governments should work together to support the executive element in order to work with more professional. This is due to implementing elements are the most important aspects for optimizing the implementation of labor policy in North Konawe. Central Government, Provincial Government and Local Government should provide:

a. Ambulance

b. Assistance of health tools which is needed by midwife

c. Wireline communication tool or as soon as possible in cooperation with telecomunication companies to build mobile telecommunication tower

d. Hastening the aid of electricity, either PLN or solar power.

e. Promote socialization so that people know the benefits Delivery Guarantee/Jampersal Program

f. Cooperation with Shaman's baby in the implementation Jampersal

\section{Acknowledgements}

I said thanks to the Rector of Diponegoro University, Dean of the Faculty of Social and Political Sciences and Regents North Konawe who have helped and supported the writing of this article.

\section{References}

BPS. (1990). Indikator Kesejahteraan Rakyat 1989. Jakarta: Biro Pusat Statistik.

Dunn, W. N. (2000). Analisis Kebijaksanaan Publik. Alih Bahasa: Muhadjir Darwin. Yogyakarta: Hamindita Offset.

Dunsere, A. (1978). Implementation in bereaucracy. Martin Robertson, Oxford.

Edwards III, \& George, C. (1980). Implementing Public Policy. Congressional Quarterly Inc. Washington D.C.

Gogin, M. L., \& Bowman, O. M., Lester, J. P., \& Toole, L. J. O. (1990). Implementation Theory and Practice: Toward and Third Generation. Scoot, Foresman and Company, Illinois.

Grindle, M. (1980). Politics and Policy Implementation in the Third World. New Jersey: Princeton University Press.

Hariyanto. (2009). Analisis Jaminan Kesehatan Masyarakat (Jamkesmas), dalam menjamin kesehatan masyaraka. yang disahkan oleh SK Menkes No. 125 tahun 2008. Jakarta. 
Jones, C. O. (1984). An Introduction to The Study Of Public Policy. California, Monterey.

Khotib. (2009). Implementasi Kebijakan Jaminan Kesehatan Masyarakat (JAM-KESMAS) Study Pada Dinas Kesehatan Kabupaten Pasuruan. Bandung Pascasarjana.

Laporan Seksi Bimdal Yankesdas Tahun 2010

Statistik Sulawesi Tenggara 2010

Undang-Undang Dasar. (1945). Citra Umbara, Bandung, 2004.

Undang-Undang Nomor 32 Tahun. (2004). tentang Pemerintahan Daerah. Citra Umbara, Bandung, 2004.

Undang-Undang Nomor 36 Tahun. (2009). tentang Kesehatan. Jakarta: Toko Gunung Agung.

\section{Copyrights}

Copyright for this article is retained by the author(s), with first publication rights granted to the journal.

This is an open-access article distributed under the terms and conditions of the Creative Commons Attribution license (http://creativecommons.org/licenses/by/3.0/). 